Zalejski J., Rola konsultacji spotecznych w zarzq̨dzaniu jednostkq samorządu terytorialnego na przykładzie Gminy Wasilków, „Ekonomia i Prawo”, Polszakiewicz B., Boehlke J. (red.), Tom XII, nr 1/2013, ss. 47-56 DOI: http://dx.doi.org/10.12775/EiP.2013.004

\title{
ROLA KONSULTACJI SPOŁECZNYCH W ZARZĄDZANIU JEDNOSTKA SAMORZĄDU TERYTORIALNEGO NA PRZYKŁADZIE GMINY WASILKÓW
}

\section{STRESZCZENIE}

W opracowaniu zostanie przedstawiona problematyka konsultacji jako przejawu partycypacji społecznej. Autor stawia sobie za cel ukazanie roli i znaczenia konsultacji społecznych w zarządzaniu Gminą Wasilków. Do realizacji założeń opracowania zostaną wykorzystane dwa modele, tzn. konsultacje w opierające się narelacjach: władza-mieszkańcy oraz władza-inwestor-mieszkańcy.

Słowa kluczowe: konsultacje społeczne, zarządzanie jednostką samorządu terytorialnego, komunikacja

Klasyfikacja JEL: M3, M38, Z1, Z18

\section{THE ROLE OF SOCIAL CONSULTATION IN THE MANAGEMENT OF A LOCAL GOVERNMENT UNIT: THE CASE STUDY OF WASILKÓW}

\section{SUMMARY}

This article draws mostly on the issue of consultation as a manifestation of social participation. The author aims to show the role and importance of public consultation

* Jarosław Zalejski, Politechnika Białostocka, Wydział Zarządzania, Katedra Marketingu i Przedsiębiorczości, ul. Ojca Tarasiuka 2, 16-001 Kleosin, e-mail: jzalejski@pb.bialystok.pl. 
in the management of gmina (administrative district) Wasilkow. To achieve the purpose of this study, two models will be used, i.e. consultations based on the relations: the government - the residents and the government - the investor - the residents.

Keywords: public consultation, management of the local government unit, communication

JEL Classification: M3, M38, Z1, Z18

\section{WSTĘP}

Partycypacja społeczna jest istotnym elementem zarządzania sferą publiczną, w której decyzje dotyczące różnicy interesów, potrzeb i oczekiwań nie powinny być rozwiązywane wyłącznie dzięki mechanizmom rynku czy drogą administracyjną, ale poprzez negocjacje i uzgodnienia. Wprowadzenie tego typu mechanizmów pozwala stworzyć efektywny system zaspokajania potrzeb społecznych, uzyskać społeczną akceptację dla podejmowanych decyzji oraz ich optymalizację.

Przejawem partycypacji społecznej są konsultacje, mające większy lub mniejszy stopień sformalizowania. O skali sformalizowania konsultacji społecznych decydują społeczności lokalne (ustalenie przedmiotu konsultacji, sposobu i zakresu oraz prezentacji wyników). W niektórych ustawach ${ }^{1}$ znaj- $^{-}$ dują się przepisy, które wprowadzają obowiązek zasięgania opinii lub wysłuchania organizacji społecznych, których dotyczy projektowane rozstrzygnięcie, np. decyzje związane $\mathrm{z}$ ochroną środowiska i $\mathrm{z}$ ochroną przyrody ${ }^{2}$. Konsultacje społeczne są zatem jednym $z$ istotnych środków osiągania celów w polityce, ale ich proces nie jest jednak zarezerwowany wyłącznie dla administracji publicznej. Współcześnie coraz częściej procesy konsultacyjne są prowadzone przez inne podmioty, których skutki działań mają charakter publiczny, np. środowiska biznesu ${ }^{3}$. Powyższe kwestie będą przedmiotem niniejszego artykułu.

${ }^{1}$ Ustawa z 27.04.2001r. - Prawo ochrony środowiska (Dz.U. 2008, Nr 25, poz. 150 ze zm.); Ustawa z 9.11.2000r. o dostępie do informacji o środowisku i jego ochronie oraz o ocenach oddziaływania na środowisko (Dz.U. 2000, Nr 109, poz. 1157 ze zm.); Ustawa z 27.03.2003 r. o planowaniu i zagospodarowaniu przestrzennym (Dz.U. 2003, Nr 80, poz. 717 ze zm.); Ustawa z 7.07.1994r. - Prawo budowlane (Dz.U. 2006, Nr 156, poz. 1118 ze zm.).

${ }^{2}$ D. Kijowski, Partycypacja obywatelska w samorzadowych procesach decyzyjnych - zagadnienia ogólne, „Samorząd Terytorialny”, 2010, nr 1-2, s. 15-16.

${ }_{3}$ D. Długosz, J. J. Wygnański, Obywatele wspótdecyduja. Przerwodnik po partycypacji spotecznej, Stowarzyszenie na rzecz Forum Inicjatyw Pozarządowych, Warszawa 2005, s. 23. 


\section{ISTOTA KONSULTACJI SPOŁECZNYCH}

Szeroko rozumiana partycypacja społeczna uwzględnia wiele metod. Wśród nich można wyróżnić trzy podstawowe formy ${ }^{4}$ :

— informowanie - administracja informuje o decyzjach lub procedurach, które dotyczą obywateli. Może przybierać formę bierną, poprzez dostęp do informacji lub aktywną, np. zebrania wiejskie, ogłoszenia itp.;

- konsultowanie - administracja proponuje rozwiązania i zbiera opinie mieszkańców na ich temat;

- współdecydowanie - budowaniu rozwiązań wspólnie ze społecznością lokalną. Strony wspólnie definiują problemy i szukają optymalnych rozwiązań.

Pierwsza forma ma charakter jednostronny, druga wzajemny (struktura konsultacji ma charakter „pytanie - odpowiedź”), trzecia oznacza dialog, wspólne dochodzenie do rozwiązań lub delegowanie części uprawnień na partnerów.

Konsultacje społeczne są „sposobem uzyskiwania opinii, stanowisk, propozycji itp. od podmiotów (instytucji lub osób), których w pewien sposób dotkną, bezpośrednio lub pośrednio, skutki proponowanych przez administracje działań. [...] Konsultacje są także wymianą informacji z opinią publiczną, dyskusją, dzieleniem się wiedzą, a nawet (do pewnego stopnia) władzą" ${ }^{5}$.

Konsultacje powinny mieć charakter pro aktywny (wyprzedzający), a nie reaktywny (działania ratunkowe $\mathrm{w}$ przypadku napięcia między partnerami społecznymi). Inicjowanie ich ma być elementem działania nowoczesnej administracji, a nie komunikowaniem decyzji już podjętych.

Podstawą do przeprowadzania konsultacji na poziomie samorządowym są przepisy ustaw o: samorządzie gminnym z 8.03.1990 r., samorządzie powiatowym z 5.06.1998 r., samorządzie wojewódzkim z 5.06.1998 r. oraz działalności pożytku publicznego i o wolontariacie z 24.04.2003 r. Zgodnie z nimi organy jednostek samorządu terytorialnego mogą przeprowadzać konsultacje społeczne w wypadkach przewidzianych ustawą (konsultacja jest wtedy obowiązkowa) oraz $\mathrm{w}$ innych ważnych sprawach $\mathrm{z}$ mieszkańcami gminy, powiatu czy województwa ${ }^{6}$. Mogą one przybierać różne formy ${ }^{7}$ :

— przedstawienie opinii publicznej w formie zwyczajowo przyjętej (sondaże uliczne i internetowe, wywiady kwestionariuszowe);

${ }^{4}$ Ibidem.

${ }^{5}$ Ibidem.

${ }^{6}$ Co to sq konsultacje spoteczne?, http://administracja.ngo.pl/x/340786.

${ }^{7}$ Konsultacje spoteczne w samorzadzie terytorialnym, http://www.samorzad.lex.p1/czytaj// artykul/konsultacje-spoleczne-w-samorzadzie-terytorialnym. 
- przedstawienie pisemnych opinii organizacji lub osób uznanych za autorytety w sprawie;

- spotkania dyskusyjne z różnymi grupami społecznymi;

- uzgodnienia między instytucjami $\mathrm{w}$ formie wynikającej z przepisów prawa (zgłaszanie uwag do dokumentów);

- powoływanie i działalność rad obywatelskich, np. rady sołeckiej;

- warsztaty strategiczne w grupach nominalnych, najczęściej z wykorzystaniem „burzy mózgów”;

- plenarne konferencje poszukiwawcze plenarnej z udziałem ekspertów zewnętrznych (wykorzystanie potencjału naukowego pracowników uczelni wyższych);

- rozprawy administracyjne, otwarte dla społeczeństwa (art. 89 Kodeksu postępowania administracyjnego;

- metoda delficka - ankietowanie dużej grupy ekspertów w kilku etapach, gdzie przy powtórnym ankietowaniu wyklucza się odpowiedzi skrajne.

Konsultacje społeczne mogą mieć charakter bierny i czynny. Konsultacje bierne uwzględniają jednokierunkową komunikację, w której mieszkańcy informowani są o przebiegu i wynikach prac prowadzonych w ramach podejmowania decyzji przez samorząd. Realizowane są między innymi przez: audycje $\mathrm{w}$ radio i telewizji, artykuły prasowe, organizowanie przez gminy imprez o charakterze ponadlokalnym oraz działania promocyjne. Konsultacje czynne stanowią dwukierunkową komunikację. Mieszkańcy są zarazem odbiorcami i jednocześnie mogą reagować na przekazywane informacje. Do form konsultacji czynnych zalicza się: spotkania konsultacyjne, spotkania prezentacyjne, warsztaty projektowe, zebrania wiejskie, debaty społeczne, badania ankietowe, forum społeczności lokalnej czy wykorzystanie sieci Internet (np. poczta elektroniczna czy fora dyskusyjne na stronach WWW gminy) ${ }^{8}$.

Wymienione metody z powodzeniem mogą być stosowane jako jedyne oraz w formie mieszanej. Połączenie różnych form konsultacji społecznych pozwala stworzyć ustalenia o charakterze kompletnym, które ukazują szerokie spektrum i wrażliwość społeczną.

\section{PRZYKŁADY PROWADZENIA KONSULTACJI SPOŁECZNYCH W GMINIE WASILKÓW}

Przedstawione poniżej działania mają na celu pokazanie, że prowadzenie konsultacji społecznych w sposób odpowiedzialny jest nie tylko możliwe, ale

\footnotetext{
${ }^{8}$ Por: J. Hausner (red.), J. Górniak, S. Kołdras, S. Mazur, R. Paszkowska, Komunikacja i partycypacja spoteczna. Poradnik, Kraków 1999, s. 34-36.
} 
także korzystne dla każdej ze stron, których dotyczy przedsięwzięcie. Wskazane przykłady mogą posłużyć jako inspiracja wprowadzenia dobrych praktyk w innych jednostkach samorządu terytorialnego oraz wyeliminować błędy, które miały miejsce w zarządzaniu Gminą Wasilków. Przykłady zostały dobrane zgodnie $\mathrm{z}$ przyjętymi modelami relacji w konsultacjach społecznych, tzn. wtadza-mieszkańcy oraz wtadza-inwesto-mieszkańcy.

\section{MODEL: WŁADZA-MIESZKAŃCY}

Konsultacje społeczne z mieszkańcami Gminy Wasilków obligatoryjnie przeprowadza się przy:

- uchwalaniu miejscowego planu zagospodarowania przestrzennego (np. we wsi Katrynka);

— uchwalaniu programów współpracy z organizacjami pozarządowymi na dany rok;

- uchwalaniu Strategii Rozwoju Gminy 2012-2020 - konsultacje z mieszkańcami oraz zespołem ekspertów reprezentujących organizacje pozarządowe i lokalnych liderów;

- uchwalaniu wieloletnich planów inwestycyjnych;

- zmiany planu sieci szkół (np. likwidacja Filii Szkoły Podstawowej w Dąbrówkach w 2012 r.

Fakultatywne konsultacje społeczne ograniczały się w 2012 roku do spotkań z mieszkańcami (zebrania wiejskie), czy konsultacji z liderami jednostek pomocniczych oraz spotkań dyskusyjnych z różnymi grupami społecznymi (Towarzystwo Przyjaciół Ziemi Wasilkowskiej im. ks. Wacława Rabczyńskiego czy Zielony Wasilków). Nową formą konsultacji, która będzie realizowana na terenie Wasilkowa, będą spotkania Przewodniczącego Rady Miasta z mieszkańcami. Pierwsze spotkanie planowane jest w listopadzie 2012 r. Spotkania będą dotyczyły bieżących spraw związanych z zarządzaniem Gminą. Tematem pierwszego spotkania będzie analiza dokumentu Strategii Rozwoju Gminy Wasilków na lata 2012-2020.

W marcu 2012 r. po raz pierwszy władze Gminy (z inicjatywy autora opracowania) zdecydowały się na konsultacje z mieszkańcami wsi Studzianki dotyczące planowanego opracowania miejscowego planu zagospodarowania przestrzennego, z przeznaczeniem terenu pod usługi i przemysł nieuciążliwy dla mieszkańców i środowiska naturalnego. Plan dotyczy 14 ha w bezpośrednim sąsiedztwie wysypiska odpadów w obrębie geodezyjnym Studzianek i Wasilkowa. Konsultacje miały charakter intencyjny, z czego wynika, że nie zostały podjęte żadne decyzje w kierunku realizacji planu. Decyzję o konsul- 
tacjach podjęto, ponieważ wiele decyzji władz Gminy, dotyczących inwestycji we wsi Studzianki i okolicach, doprowadziło do protestów mieszkańców. Protestami mieszkańców zainteresowała się telewizja TVN24, która nadała szereg programów na temat inwestycji w okolicach wsi Studzianki. Dotyczyły one budowy Wytwórni Mas Bitumicznych (inwestycja powstała z naruszeniem prawa; powstała na terenie kopalni kruszywa i bez wiedzy władz Gminy) oraz Centrum Innowacyjnej Gospodarki Odpadami (na terenie inwestora doszło w styczniu 2012 roku do pożaru składowanych śmieci przeznaczonych do sortowania). Aby uniknąć konfliktowych decyzji postanowiono zapytać mieszkańców o ich opinie na temat planowanych zmian w zakresie miejscowego planu zagospodarowania przestrzennego. Jako formę konsultacji przyjęto badania ankietowe ${ }^{9}$, które planowano przeprowadzić z jedną osobą, która reprezentowała poszczególne gospodarstwo domowe w Studziankach. Na okoto 200 gospodarstw domowych w konsultacjach społecznych wzięło udział 111 mieszkańców Studzianek. Pozostali mieszkańcy albo nie chcieli uczestniczyć w badaniach, albo byli w tym czasie nieobecni. Kwestionariusz ankietowy zrealizowano wśród 55 kobiet i 56 mężczyzn. 81 respondentów było w wieku od 35-64 lat. W 78 gospodarstwach domowych, w których byli respondenci, nie było osób bezrobotnych. Wyniki badań pokazały, że większość respondentów pozytywnie oceniło planowane zmiany w miejscowym planie zagospodarowania przestrzennego, co przedstawia wykres 1 .

Respondenci, którzy nie chcą, aby władze podejmowały pracę nad planem, zwracali szczególnie uwagę na następujące problemy: nie jest określone, co ma powstać na tym terenie (6 osób) oraz obawa przed budową następnej sortowni, zmiany zagrażają środowisku, uciążliwość przemysłu (po 3 osoby). Wyniki badań nie potwierdziły opinii przedstawianych przez liderów Stowarzyszenia „Demoskratos” oraz tez stawianych w programach TVN24, że wszyscy mieszkańcy Studzianek są przeciwni inwestycjom przemysłowym na tym terenie. Konsultacje w tym przypadku miały charakter pro aktywny i stanowiły pierwszy etap w wypracowaniu optymalnych rozwiązań decyzyjnych dotyczących zagospodarowania przestrzennego w okolicach wsi Studzianki.

9 Badania koordynował dr Jarosław Zalejski. Ankieterami byli studenci Politechniki Białostockiej (Przemysław Dowgiert, Justyna Grudzińska, Tomasz Ignatowicz, Katarzyna Łotowska, Marzena Poskrobko, Karolina Przychodzka, Paulina Redo, Marta Zdanewicz). Kwestionariusz ankietowy składał się z dwóch części oraz metryczki. Pierwsza (z mapą obszaru objętego planem) została opracowana przez koordynatora badań. Drugą opracowali studenci (wymienieni powyżej) pod kierunkiem dr. Jarosława Zalejskiego. Wyniki badań, z drugiej części kwestionariusza, wykorzystane zostały przez studentów do opracowania projektu zaliczającego przedmiot Kampanie promocyjne. 


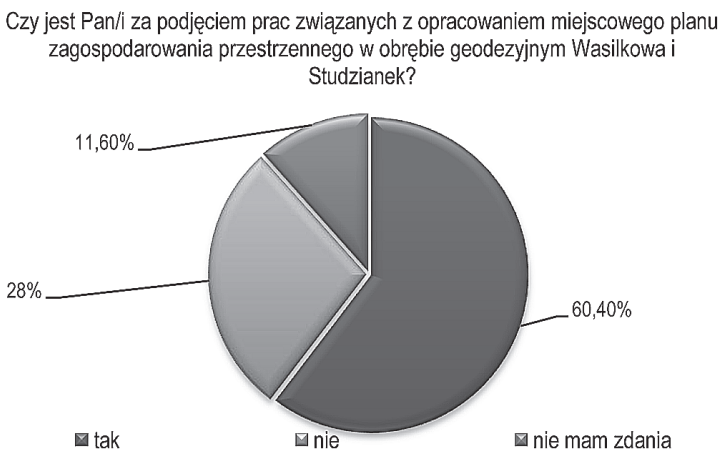

Wykres 1. Wyniki badań przeprowadzonych 31 marca 2012 w Studziankach Źródło: opracowanie własne.

\section{MODEL: WŁADZA-INWESTOR-MIESZKAŃCY}

Konsultacje pomiędzy trzema podmiotami są nowym zjawiskiem na terenie Gminy Wasilków. Ten typ konsultacji staje się koniecznością w zarządzaniu jednostką samorządu terytorialnego. Szczególne znaczenie nabiera w przypadku Gminy Wasilków, gdzie niejednokrotnie dochodzi do konfliktów interesów w relacjach między tymi podmiotami. Konflikty te mają podłoże związane $\mathrm{z}$ brakiem informowania mieszkańców o planowanym wejściu na rynek nowego podmiotu gospodarczego oraz o możliwych wzajemnych korzyściach wynikających z pozyskania inwestora na teren Gminy. Czasami konsultacje trójstronne stanowią jedyną metodę rozwiązania konfliktu, jak w przypadku inwestycji już realizowanych, np. budowa drogi we wsi Jurowce ${ }^{10}$.

Jak już wcześniej wspomniano, konsultacje powinny mieć charakter wyprzedzający. Jednak, w niektórych przypadkach, konsultacje reaktywne są niezbędne, aby zmienić negatywny wizerunek inwestora na rynku, a także zmienić stosunek części mieszkańców do niepopularnych decyzji władz gminy. Taka sytuacja miała miejsce w Gminie Wasilków, w przypadku budowy Cen-

10 Podczas realizacji budowy drogi doszło do konfliktów na linii wykonawca-mieszkańcy. Związane to było z faktem, że plan wykonawczy odbiegał od oczekiwań wielu mieszkańców. W wyniku wizji lokalnej w maju 2012 r. doszło do korekt w realizacji inwestycji i konflikt w znacznym stopniu został ograniczony. W wizji lokalnej uczestniczyli: przedstawiciele Starostwa Powiatowego (właściciel drogi i inwestor), pracownicy Urzędu Miasta (przedstawiciel inwestora), przedstawiciele Rady Miasta, kierownik robót oraz sołtys wsi Jurowce. 
trum Innowacyjnej Gospodarki Odpadami (CIGO). Okoliczności, które miały miejsce w przypadku realizacji inwestycji, były od początku niesprzyjające. Teren, na którym zlokalizowano CIGO, jest w bliskim sąsiedztwie wstrzymanej budowy wytwórni mas bitumicznych oraz wysypiska zarządzanego przez Związek Gmin „Czyste Środowisko”. Sytuację jeszcze bardziej skomplikował wybuch pożaru składowanych odpadów (20 tyś ton), które miały być przeznaczone do rozruchu sortowni. Fakt ten spowodował zainteresowanie mediów, czego przykładem było wyświetlenie kilku programów przez telewizję TVN24, w których bardzo negatywnie oceniono Inwestora i władze Gminy.

W tak niesprzyjających okolicznościach, $\mathrm{z}$ inicjatywy Przewodniczącego Rady Miasta, władze Gminy zdecydowały się na przeprowadzenie badań ankietowych ${ }^{11}$ we wsi Studzianki. Celem badań było poznanie opinii mieszkańców na temat realizowanej inwestycji oraz pokazanie jakie błędy popełniła Gmina i Inwestor, po podjęciu decyzji o lokalizacji tego typu inwestycji na tym obszarze. Wyniki badań pokazały, że podstawowym zaniedbaniem ze strony zarządzających, był brak jakichkolwiek informacji na temat budowy CIGO (79\% respondentów odpowiedziało, że nie przekazano mieszkańcom żadnych informacji dotyczących budowy i działania sortowni odpadów w Studziankach, a 87\% wyraziło niezadowolenie z tego faktu). Respondenci zwracali uwagę na brak poinformowania w takich kwestiach jak: czy inwestycja nie zagraża środowisku naturalnemu, jakie zastosowano rozwiązania technologiczne w CIGO oraz jakie korzyści z inwestycji będą mieli mieszkańcy wsi Studzianki i Gminy. 86\% respondentów uważało, że należy zorganizować zebranie wiejskie w celu wyjaśnienia powyższych kwestii. Efektem przeprowadzonych badań było przygotowanie kampanii public relations „Słucham, pytam, rozumiem”, która ukierunkowana jest głównie na mieszkańców Sołectwa Studzianki. Zarządzający CIGO w Studziankach pozytywnie ocenili zakres programu działań, który został nakreślony w opracowaniu. Program kampanii uwzględnia takie działania jak:

spotkanie Zarządu CIGO z mieszkańcami Studzianek w celu wyjaśnienia obaw związanych z funkcjonowaniem sortowni;

- wspieranie działań o charakterze społecznym na obszarze Gminy, czego przykładem jest remont drogi (zrealizowano pierwszą część planowanych działań) w Horodniance (sołectwo Studzianki), czy też sponsoring zespołu piłkarskiego KS „Studzianki” (umowa w trakcie realizacji);

— organizacja „Dni Otwartych CIGO” w Studziankach;

${ }_{11}$ Badania ankietowe przeprowadzone przez studentów Wydziału Zarządzania Politechniki Białostockiej w 31 marca 2012 r. w Studziankach, których koordynatorem był dr Jarosław Zalejski. 
- aktywizacja mieszkańców w promowaniu polityki czystego środowiska. Zaproponowane działania uwzględniają wnioski z konsultacji pomiędzy zarządzającymi Gminą Wasilków a inwestorem.

\section{ZAKOŃCZENIE}

Konsultacje społeczne są jednym $\mathrm{z}$ elementów utrzymywania więzi komunikacyjnych władzy z mieszkańcami gminy. Komunikacja taka jest jednym z niezbędnych warunków nowoczesnego zarządzania jednostkami samorządu terytorialnego. Nowe tendencje w zarządzaniu sprawami publicznymi oraz coraz wyższa świadomość społeczna o możliwościach wpływu mieszkańców na decyzje władz, które ich dotyczą, sprawia, że konsultacje o charakterze fakultatywnym przybierają formę w pewnym sensie obowiązkowych. Mieszkańcy stosunkowo wcześnie mogą proponowane inicjatywy zablokować lub poprzeć, zmodyfikować ich kształt lub zbudować koalicje na rzecz ich wprowadzenia. Udział rożnych podmiotów w procesach komunikacyjnych i informacyjnych służy także budowaniu kontroli społecznej, pobudza świadomość odpowiedzialności społeczności lokalnej za podejmowane decyzje. W rezultacie czego, władze uzyskują poniekąd współodpowiedzialność mieszkańców w stosunku do uzgodnionych z nimi programów działań.

Wyniki konsultacji społecznych, realizowanych w Gminie Wasilków, w coraz większym zakresie wpływają na proces podejmowania decyzji. Uwzględnienie konsultacji jako elementu zarządzania powoduje, że:

- najbardziej skomplikowany projekt inwestycyjny może być zrealizowany, gdy prowadzone będą działania informacyjne od najwcześniejszego etapu inwestycji;

- powstanie inwestycji korzystnej ekonomicznie, społecznie i spełniającej wymogi ochrony środowiska zależy od współpracy wszystkich zainteresowanych stron;

- konsultacje budują zaufanie społeczne, które ułatwia realizację kolejnych inwestycji (dotyczy to zarówno nowych inwestorów, jak również planowanie kolejnych inwestycji przez inwestora, którego te konsultacje dotyczyły);

- wprowadzenie szeroko pojętych konsultacji społecznych pozwala zbudować pozytywny wizerunek własny i zwiększyć zaufanie w stosunku do zarządzających Gminą. 


\section{BIBLIOGRAFIA}

Co to sq konsultacje spoteczne?, http://administracja.ngo.pl/x/340786.

Długosz D., Wygnański J. J., Obywatele wspótdecyduja. Przewodnik po partycypacji spotecznej, Stowarzyszenie na rzecz Forum Inicjatyw Pozarządowych, Warszawa 2005.

Hausner J. (red.), Górniak J., Kołdras S., Mazur S., Paszkowska R., Komunikacja i partycypacja spoteczna. Poradnik, Kraków 1999.

Kijowski D., Partycypacja obywatelska w samorzadowych procesach decyzyjnych - zagadnienia ogólne, „Samorząd Terytorialny”, 2010, nr 1-2.

Konsultacje spoteczne w samorządzie terytorialnym, http://www.samorzad.lex.pl/czytaj/-/ artykul/konsultacje-spoleczne-w-samorzadzie-terytorialnym.

Ustawa z 27.04.2001 r. - Prawo ochrony środowiska, Dz.U. 2008, Nr 25, poz. 150 ze $\mathrm{zm}$.

Ustawa z 9.11.2000 r. o dostępie do informacji o środowisku i jego ochronie oraz o ocenach oddziaływania na środowisko, Dz.U. 2000, Nr 109, poz. 1157 ze zm.

Ustawa z 27.03.2003 r. o planowaniu i zagospodarowaniu przestrzennym, Dz.U. 2003, $\mathrm{Nr} 80$, poz. 717 ze zm.

Ustawa z 7.07.1994 r. - Prawo budowlane, Dz.U. 2006, Nr 156, poz. 1118 ze zm. 